\title{
Prefixation in English and Albanian languages
}

\author{
Ma. PhD. Cand., Olsa Xhina \\ Lecturer of English Language, Department of Foreign Languages \\ Faculty of Education, "Aleksander Moisiu" University, Durres, Albania \\ Mob: 0672028 229, olsa.xhina@gmail.com
}

Doi:10.5901/ajis.2013.v2n8p253

\begin{abstract}
Word-formation process is of great interest to the linguists as they affect the language vocabulary enhancement. In both English and Albanian languages one of the most productive word-formation processes is derivation including prefixation and suffixation. Prefixation is a way of enlarging vocabularies and forming new lexical forms. Prefixes are classifying, they do not change the lexico-grammatical category of the word. This paper aims at studying some crucial issues on prefixation in both English and Albanian languages. It will analyze the characteristics of English and Albanian prefixes in a various ways; their types and classifications in both languages by comparing and contrasting. The classification is mostly done basing on different principles related to some of their typical features and their meanings. These will be studied into depth in order to examine the productivity by means of prefixation in both languages.
\end{abstract}

Keywords: wordformation, prefixation, suffixation, derivation, prefixes classification.

\section{Introduction}

Interest in wordformation processes is probably as old as interest in language itself. Many of the questions that scholars are asking now were also being asked in the seventeenth, eighteenth and nineteenth centuries. (Bauer,1983). Thus, the study of affixattion and especially prefixation is of great interest to the linguists as it affects the vocabulary enhancement in all methods it is presented.

This paper aims to study the processes of prefixation, as a very important derivation sub type used in the English language system, by providing an overview of the English prefixes, their most important features and classifications. In addition, the study will also treat crucial prefixation issues in the Albanian language by comparing and contrasting these issues in both languages.

In order to understand the meaning of the 'term' prefix, we should take into consideration the internal structure of the word, that is the 'morpheme', the smallest meaningful component in a language. The morphemes are divided into free morphemes, which are independent and can stand alone or within a word and bound ones, which can not stand alone and consequently always occur in combination with basic forms. The adding of these bound morphemes to the basic forms is called affixation. As a rule, prefixes are bound morphemes which precede the base or the free morphemes. Prefixation is a special affixation formation subtype among suffixation and prefixo-suffixation. In Albanian language it is an important derivation subtype, but not as suffixation. The prefixes of the English language are classifying; In most cases there is no change of the word class involved. (Kortmann 1999). As for their meaning and function, linguists notice that there are living prefixes, productive prefixes and fossilised ones in certain words.

It is difficult to define the exact number of prefixes in English language, though there are more prefixes than suffixes. OED registers 167 prefixes, but according to Marchand (1969) there are 65 such.

\subsection{Classification of prefixes}

There are diferent principles apon which various classifications of prefixes are done. In this paper we will introduce various classifications, based on morphological, and semantic features of prefixes. Other relevant issues and characteristics will be treated throughout the study as well for both languages.

Morphologically, many affixes are associated with specific word classes; for example the prefix il- as in illegal, is attached to adjectives. Undeniably, some prefixes attach to nouns, whereas others combine only with adjectives or verbs. However, apart from the prefixes which are associated with one specific word class, there are also a number of them 
which associate with more than one inherent word class. For ex. the prefix dis- can form the verb dislike, the adjective dishonest, or it can be part of the noun dishonesty.

Another example is the prefix un- which can form an adjective (untity), a verb

(undo) or a noun (unemployment).

Secondly, by means of derivation process the majority of English prefixes are able to create new words or lexemes, but they cannot change the word class of the derived word; to reuse.(v) - use (v); untidy (adj) - tidy.

There are only a few prefixes which cause a change of the category such as: -en in enlarge, -a in or ablaze. Other exceptions are em-, be-, and de-. (Lenski 2000). In Albanian language there is a minor number of such prefixes as well which change the word class they are attached to, for e.g.: përbuz.v - to despise (buzë, n.), shfaq v. - to appear - (faqe, n.), përgjak to bleed (gjak); the prefixes: për-, sh-, are attached to the nouns buzë, faqe, gjak and have formed verbs, changing the grammatical category of the new word.

Lenski is not sure whether the prefix - $a$ and -be as in ashore ashore (on/ towards shore)

or belie ('lie near' cf. underlie). (Lenski 2000)]. The vast majority of prefixes do not change the syntactic category of their base words, they merely act as modifiers. Furthermore, it can be observed that most of the 51 prefixes of Modern English generally attach to more than one kind of syntactic category (verb, adjective, or noun) and do not influence the stress pattern of their bases.

As to the type of lexico-grammatical character they are added to, English prefixes fall into: a. Deverbal prefixes, e.g. rewrite, outstay, overdo, oversleep, overreact, underestimate; b. Denominal prefixes, e.g. ex-president; c. Deadjectival prefixes, e.g. unedited, bilateral, uneasy, biannual, etc.

\subsection{The classification of English prefixes on the basis of meaning}

Semantically prefixes fall into mono and polysemantic.

Linguists refer to these different categories of English prefixes in terms of generic denotational meaning:

Prefixes of attitude: pro, anti, contra, counter, co.

Pro: pro-choice, pro-life, pro-market, pro-libertarian. It is usually added to nouns, adjectives of denomination.

Anti : anti-missile, anti-social, antibody, anti-abortion, anti-regulatory; = antagonistic: anti-hero, antichrist. This prefix is added to nouns, adverbs, denominal adjectives.

Counter : to counteract, counter-revolution, counter-example, counter-espionage, counter-productive; added to: verbs, abstract nouns, adjectives.

Contra: contraception, contradistinction; added to: abstract nouns, verbs.

Co: cooperate, co-pilot, co-author, cooperation; added to: nouns, verbs;

Reservative and deprivative Prefixes: un, de, dis.

Un: to untie, to unpack, to unhorse, to unscramble, to unlock. It is usually added to verbs. De: to decriminalize, to deselect, to decontaminate, to debug, to defrost, to delouse, to deplane, to detrain, to decamp, deforestation; It is added to verbs, abstract nouns.

Dis: to disqualify, to disinvite, to disenfranchise, to disarm, to disillusion, to disambiguate, discoloured, disconnected, discontent, dissatisfaction; It is added to verbs.

Negative Prefixes: a-, dis-, non-, un-

A: atheist, amoral, asymmetry, apolitical, asexual; It is added to adjectives and nouns; Dis: disloyal, distrust, disagree, dislike, disfavour, disadvantage; added to: adjectives, abstract nouns, verbs; Un: in-, il-(before I), im-(before p), ir-(before r); unfair, unassuming, unexpected, unproductive, insane, injustice, intolerance, impatience, imperfect, irregular, illegal, incapable, illogical, improper, irrelevant. These are added to: adjectives, participles (only un-); Non: non-stop, noninterference, non-aggression, non-smoker, non-drip (paint), non-person, non-event; This prefix is added to various types of words and expressions, mainly nouns and verbs.

Pejorative prefixes: mis-, mal-, pseudo-, crypto-

Mis: mismanagement, to miscalculate, to misgovern, to mishandle, misleading, misconduct, to misinform (inform wrongly; It is added to verbs, abstract and participles: Mal: means bad(ly), improper(ly): malpractice, malinformation, malnutrition, maltreatment, to malfunction, maladjusted, malformed; It is added to verbs, abstract nouns, participles, adjectives, but only words of latin origin.

Pseudo: pseudo-education, pseudo-intellectual, pseudo-science, pseudo-Gothic; It is added to nouns and adjectives; Crypto: crypto-fascist, crypto-Catholic, cryptography; it is added to nouns.

Locative prefixes: ante, circum, fore, inter, intra, mid, out, over, retro, sub, super, supra, sur, ultra, under. 
Ante: antechamber, anteroom; It is added to: nouns; Circum: circumnavigate, circumlocution, circumcision; It is added to: verbs and nouns; Extra: extramarital, extracurricular, extrasensory, extra-pay; It is added to: adjectives and nouns; Fore = in front, front part of: forefinger, foreskin, forecourt, forehead. It is added to nouns; In: also il-, im-, ir- ingathering, indoors, in-patient (not impatient); added to: participles, nouns; Inter. interracial, international, interdisciplinary; added to: adjectives and nouns; Intra: intramural, intra-uterine, intravenous; It is added to: adjectives; Mid: midfield, mid-point, midway; added to: nouns; Out: outdoor, out-patient, outlook; added to: nouns; = to surpass: to outrun, to outnumber, to outgrow, to outdistance, to outbid; added to: verbs; Over: to overthrow, to overshadow, overcoat; added to: verbs, nouns; = excessive: overemphasis, over-anxious, to overcharge, to overfish; added to: nouns, verbs; Retro: to retroflex, to retrorocket, to retroject; added to: verbs; Sub: subway, subsoil, subconcious; added to: nouns, adjectives; = secondary, lesser in rank: sub-editor, subdean, subleader, sub-climax; added to: nouns; = subordinate part of: subcommittee, subplot, sublet, subtitle; added to: nouns; = below the norm: subhuman; Super: superstructure, superimpose, superterrestrial; added to: nouns, verbs, adjectives; beyond the norm:superhuman, superman, supergun, superstar; added to: nouns, adjectives; excessive, excessively: superconformity, superconfidence, supersensitive, superabundant, supercritical; added to: nouns, adjectives; Supra: supranational, supramundane; added to: adjectives; Sur: surtax, surcharge, surtitle; nouns, verbs; Tele: telecommunication, television; added to: nouns, verbs; Trans: transatlantic, transnational, transsexual; added to: adjectives, geographical names; Ultra: ultra-violet, ultra-sonic, ultra-modest, ultra-thin, ultramodern, ultra-orthodox; added to: adjectives; Under. underground, undercarriage, underclothes; added to: nouns; = too little; undercharge, underpay, undercook, undervalue: added to: verbs; = subordinate: under-secretary, underclass.

Prefixes of Size, Degree and Status: (arch, macro, micro, mega, mini, over/under, hyper, co, pro, vice) Arch: archbishop, arch-rival, archangel, archduke, arch-enemy; added to: nouns; macro: macrocosm, macro-economics; added to: nouns; micro: micro-computer, microsurgery, micro-economics; added to: nouns; mega: megastar, megastore; added to: nouns; mini: miniseries, minibreak, minicab, miniskirt; added to: nouns; over/under: to overcook, to underheat; added to: any verb of action; hyper: hypercritical; added to: adjectives; co: co-founder, co-presenter; added to: nouns, verbs; pro: pro-vice-chancellor; added to: nouns of latin origin; vice: vice-president.

Prefixes of Time and order: ante, ex, fore, neo, post, pre: Ex: former: ex-wife, ex-president; human nouns; Fore: before: to foresee, to foretell, foregone; Mid: middle: mid-afternoon, midwinter, midnight; Neo: new, recent form of, revived: neo-colonialism, neo-conservative, neo-fascist; Post: after: post-war, post-modernism, post-structuralist; Pre: before, pre-arranged before the time/period of: prepay, pre-existing, predate, preview, preschool, pre-war, pre-marital. Prefix of repetition: re-, e.g. rebuild (build), re-write (write), etc.

In his book "The word-formation in English"(2003), Plag classifies the prefixes of English semantically into the following groups. First, there is a large group that quantify over their base words meaning, for example, 'one' (uni-, unilateral, unification), 'twice or two' (bi-, bilateral, bifurcation and di-, disyllabic, ditransitive), 'many' (multi-, multi-purpose, multi-lateral and poly-, polysyllabic, 'half' (semi-, semi-conscious, semi-desert), 'all' (omni-, omnipotent,omnipresent), 'small' (micro-, micro-surgical, microwave), 'large' (macro-, macroeconomics, macro-biotic), 'to excess' (hyper-, hyperactive, hypermarket and over-, overestimate, overtax), 'not sufficiently' (underpay).

Second, there are numerous locative prefixes such as circum- 'around' (circumnavigate, circumscribe), counter'against' (counterbalance, counterexample), endo-'internal to X' (endocentric, endocrinology), epi- 'on, over' (epiglottis, epicentral), inter-'between' (interbreed, intergalactic), intra- 'inside' (intramuscular, intravenous), para-'along with' (paramedic, paranormal), retro- 'back, backwards' (retroflex, retrospection), trans- 'across' (transcontinental, transmigrate).

Third, there are like 'before' (ante-, preand fore-, as in antechamber, antedate, preconcert, predetermine, premedical, forefather, foresee), 'after' (post-, poststructuralism, postmodify, postmodern), or 'new' (neo-, neoclassical, Neo-Latin). A fourth group consists of prefixes expressing negation (a(n)-, de-, dis-, in-, non-, un-). (Plag, 2003).

However, many prefixes do not fit into any of the four groups and express diverse notions, such as 'wrong, evil' (mal-, malfunction, malnutrition), 'badly,'wrongly' (mis-, misinterpret, mistrial), 'false, deceptive' (pseudo-), 'together, jointly', (co-), 'in place of' (vice-) etc. Above were demonstrated with examples an other classification of prefixes according to the meaning, which Plag does not include in his categories of prefixes.

\subsection{Characteristics of English prefixes}

Though the current trend in English language is avoiding the unnecessary hyphens, there are several rules that should be taken into consideration in terms of prefix-root right punctuation. 1. Thus, there must be used a hyphen when prefixes come before proper nouns. E.g.: un-American post-Aristotelian or pre-1900; 2. Hyphenating prefixes ending in 
an a or $i$ only when the root word begins with the same letter such as in ultra-ambitious or semi-invalid. Also, there must be used a hyphen to avoid confusion with another word: for example, to distinguish re-cover (= provide something with a new cover) from recover (= get well again). (J.Straus10th edition)

An English prefix requires a special stress to help in clarifying the meaning or to avoid mispronouncing, for e.g. coop, it is not the same as coop, as well as re-creation. Besides, the prefix co- is always stressed when it addresses a person. The words co-authored and co-workers are often hyphenated.

\section{The Development of English prefixes}

Throughout the centuries, the English language has been influenced by various foreign languages. Several English words are structured as a combination of dependent prefix and an independent base such as in un-just. Marchand (1969) thinks that these types of words are referred to as words formed by native word-formation processes. Other words in English are formed by foreign word-formation processes. We should say that this is also noticed in Albanian language. These word types are known as neo-classical words and are borrowed from different sources like either Greek or Latin, or have been coined upon Greek or Latin word-formation processes.

If we examine the usage of the native prefixes over the years, we have to admit that their usage today has become much more seldom than in former times. According to Marchand this is to a certain amount due to the tendency to form more and more post particle words. (Marchand 1969: 131) From Old English onwards, especially locative particles which were connected to verbs were no longer placed before, but after the verb, thus leading to a reduced usage of prefixes.

Prefixes may be also classified as to the degree of productivity into highly-productive, productive, and nonproductive. The linguist Bauer figures out the following tendencies: the prefix a- had a peak of productivity in the 19th century and is still marginally productive. The verbalising prefix be- is these days stylistically and formally restricted. The prefix mis- became contaminated with French més- and gained extra life from that. It was still marginally productive in the 20th century. The prefix un- remains extremely productive, especially when added to adjectives. (Bauer 2003:34)]

Bauer goes even so far to say that the enormous loss of productivity which is currently characteristic for most of the native affixes, will sooner or later result in the total disappearance of these affixes. Here only the prefix un- can be seen as an exception from the tendency. (Bauer 2003: 35)

Nevertheless, there is an increase on the non-native prefixes which, throughout the years, have been completely incorporated in the English language system such as French, Latin, Greek, etc.

Germanic prefixes, usually have a relatively low productivity, except the prefixes un-, under-, over-, fore- and out which can be combined with either [+Latinate] or [-Latinate] bases. (Lenski 2000:5),

According to Marchand the low productivity of Germanic prefixation has occurred since the Norman Conquest through the massive influx of French prefixes and the movement of locative particles to post-verbal position during the Middle English period. (Lenski 2000: 4-5)

Below are some prefixes listed by their origin and etymologic domain according to Lenski:

co- Latin [+/- Lat.] co-defendant; counter- Latin [+/- Lat.] counteract; de- Latin [+/- Lat.] decentralize; dis-1 Latin Most [+Lat.] displease; dis-2 Latin [+Lat.] disobedient; en-1 Latin [+/- Lat.] enclose; en-2 Latin [+/- Lat.] enchain; ex- Latin [+/- Lat.] ex-officer; extra- Latin [+Lat.] extraordinary; for- Germ. [- Lat.] forbear; fore- Germ. [+/- Lat.] foresee; hyperGreek [+Lat.] hyperactivity; in- Latin [+Lat.] infirm7 Appendix 22; mis- Multiple [+/- Lat.] misgovern; non- Latin [+/- Lat.] nondescript; over- Germ. [+/- Lat.] overdo; post- Latin [+Lat.] postpone; para- Greek [+/- Lat.] paraphysical; pre-1 Latin [+/- Lat.] prejudge; pre-2 Latin Most [+Lat.] prenatal; pro- Greek [+/- Lat.] pro-action.

\section{Some prefixation issues in Albanian language}

Prefixes in Albanian language are quite less in quantity, only one third of suffixes. Moreover, they do not have the same level of productivity as suffixes do, though prefixation remains a very important word-formation process especially in creating technical and scientific terminology. Aleksander Xhuvani has accounted 68 prefixes in his book "Prefixes of Albanian language", but many of these are not in use today such as (n-, m-, s-, a-) (Shqerra 2009).

Historically a few prefixes are known to derive from different word classes such as prepositions, adverbs or even particles transformed into prefixes, which by being placed at the beginning of the word, have changed its meaning.(Hysa, E,1973)

Besides, prefixation in Albanian language has closely developed with 'attached words pattern' or 'perngjitja', as well as compounding. Thus, certain prepositons have turned into prefixes due to the procces of 'word attaching', 
'perngjitja'; for e.g.: nëntokë (under ground) is an an attached word, nëngrup (subgroup) is a derived word in which the prefix 'nën' is placed before the base word 'grup'. Even compounding and prefixation is somehow complicating in the way words are developed. For. e.g: parashikoj, (predict) parandjenje (anticipation), parafjalë (prefix), pararojë (vanguard), etc are compound words, in which 'para' plays the role of an adverb, not that of a prefix.

According to the grammar book of the Albanian Academy of Science,"Gramatika e gjuhës shqipe"(2002), prefixes do not usually change the grammatical category in Albanian wordformation. Thus, a prefix is added to a verb to create an other verb, or added to a noun ro create an other noun, added to an adjective to form an other adjective etc. (Celiku, Karapinjalli 2007). It merely gives an other meaning to the new word of the same grammatical category which is created, which is also true for the English prefixes.

When the word class changes, the prefix is completely attached to the base and the final base vowel drops, for e.g.: përbuz.v - to despise (buzë, n.), shfaq v. - to appear - (faqe, n.), përgjak to bleed (gjak); the prefixes: për-, sh-, are attached to the nouns buzë, faqe, gjak and have formed verbs, changing the word class.

Also, prefixes in Albanian language, just like we found it in the English language, might provide the words to which they are attached with a complementary meaning.

The combination types of prefixes with roots in Albanian language are:

Prefix + a verb= verb eg.: Vlerësoj - zhvlerësoj; (estimate-underestimate)

Prefix + a noun =noun :afërsi - përafërsi (proximity- aproximacy),

Prefix + an adjective $=$ adjective eg. : i lidhur - i ndërlidhur (connected - interconnected)

Prefix + an adverb = adverb gjithmonë - përgjithmonë; (always; forever)

Furthermore, it can be observed that most of prefixes of modern Albanian generally attach to more than one kind of syntactic category (verb, adjective, or noun).

The most used prefixes are: për, mbi, nën, ndër, pa, jo, mos, sh, zh, stër, ç, ri, shpër, gjithë, pas, jashtë, sipër, vetë, gjysmë, shumë.

Për-(for) is added to verbs, to nouns, adjetives, adverbs. Examples.: (forcoj - përforcoj), (masë - përmasë).

Mbi- (over, on) is added to nouns, adjectives, verbs. Examples: (shkrim-mbishkrim), (njerezor-mbinjerezor), (zotëroj-mbizotëroj).

Nën- (under) is added to nouns, adjectives, verbs. Examples: (oficer-nënoficer), (tokesor-nëntokesor), (qeshnënqesh), etc.

Ndër-(inter) is added to verbs, adjectives, nouns.(hyj-ndërhyj); (kombëtar-ndërkombëtar); (veprim - ndërveprim).

$\mathrm{Pa}$-(without) is added to adjectives, participles to create adjectives with a negative meaning, antonyms, nouns: (i ditur - i paditur); ( i shkruar - i pashkruar); barazi - pabarazi.

Jo-(non) is added to adjectives, verbal nouns: (demokratik - jodemokratik), (besim - mosbesim).

Sh-/zh-/ç- are added to verbs to create verbs with negative meanings, adjectives: (thur- shthur); (genjej-zhgenjej); (armatos-çarmatos).

S-/z-: kuq-skuq; mbuloj-zbuloj.

Ri- (re) is added to verbs: punoj - ripunoj. (rework, work again)

Stër- is added to nouns, adjectives and verbs, for eg: (lodhje-sterlodhje), (i gjate- i stergjate); (holloj- sterholloj) etc. (Celiku, Karapinjalli 2007).

Shpër- is added to verbs with an intensive or opposite meaning: (ngul-shpërngul), (blej-shpërblej).

Porsa-; sapo- is added to participles to create adjectives with a meaning "just done":

(i ardhur- i porsaardhur); (i fejuar- i porsafejuar), etc.

Kundër $-a)$ is added to nouns:

(gaz n.-kundërgaz); (sulm n. - kundersulm) etc.

b) is added to adjectives (ligjor-kunderligjor), njerezor-kundernjerezor

Bashkë- a) is added to nouns to create nouns with a collective meaning: udhetar - bashkëudhetar; punetor bashkepunetor; autor - bashkautor etc. b) is added to verbs to create others verbs with collective meanings.eg: bisedojbashkebisedoj; punoj - bashkëpunoj etc.

Para- a) is added to verbs: (shikoj- parashikoj)

b) is added to nouns (lindje-paralindje); (provim-paraprovim)

c) is added to adjectives: (ushtarak- paraushtarak); (historik-parahistorik);

(fundor-parafundor)

Prapa- a) is added to nouns: shtesë-prapashtese, mbetje - prapambetje.

b) is added to adjectives: shtesor - prapashtesor 
Tej - a) is added to adjectives: I dukshëm- I tejdukshëm;

b) is added to verbs: kaloj -tejkaloj;

Pas - is added to nouns: ardhës - pasardhës; thënie -pasthënie. Other Albanian prefixes are: jashtë, sipër, gjithë, krye, drejt, vetë, gjysmë, shumë. (Celiku, Karapinjalli 2007).

\subsection{Foreign prefixes in Albanian language}

In addition, there is a considerable number of foreign prefixal elements such as: a-, anti-, de-, dez-, dis-, pro-, pan-, trans, ultra-, poli-, super-, auto-, inter-, etc. These are usually borrowed with the word they are pre-attached as in: anormalnormal, dezinfektoj-infektoj (disinfect - infect), disharmoni-harmoni (harmony-disharmony); in this case the foreign prefixal element is quite distingushable. Also, when there are used two derived words with the same root as in import-eksport (import-export), the foreign prefixes are easily distinguished even in terms of Albanian word-formation system. On the contrary, borrowed words such as: anarki (anarchy), antagonist (antagonist), intervistë (interview), konstrukt (construct), distinktiv (distinctive) etc., which do not fulfill the above criteria, are not considered as base words in Albanian language, though in the source language they come from they are not base words. (Fonetika dhe gramatika e gjuhes shqipe, Akademia e shkencave, 1976).

Some of the foreign prefixes are assimilated by the Albanian word-formation system in such a high level that they have started to form new words based on native roots such as: antikombëtar (anti-national), panshqiptar (pan-Albanian), etc. However, another trend noticed in the modern Albanian language is the replacement of the borrowed prefixes by Albanian ones, for eg.: kundërajror, kundërgaz (antiajror, antigaz), ndërkontinental, ndërmolekular, (interkontinental, intermolekular), çmilitarizim, shpolarizim (demilitarizim, depolarizim) etc. (Fonetika dhe gramatika e gjuhes shqipe, Akademia e shkencave, 1976).Celiku and Karapinjalli suggest other examples in their grammar book. (Celiku, Karapinjalli 2007): normal-anormal; jonormal); (fetar-afetar, irreligious; jofetar, not religious.

A- (with a negative meaning): normal-anormal; simetrik-asimetrik; fetar-afetar. (abnormal, assimetric)

An- alfabet-analfabet (illiterate)

In-; i- real-inreal; moral - imoral; legal - ilegal (illegal, immoral)

Anti- popullor-antipopullar; demokratik-antidemokratik; kombetar-antikombetar (anti-national)

De- formoj-deformoj; gradoj-degradoj; mobilizoj-demobilizoj (deform)

Dez-infektoj-dezinfektoj; integroj-dezintegroj(disinfect)

Dis- nivel-disnivel (dislevel)

Pro- amerikan- proamerikan; fashist -profashist (profascist)

In- organik -inorganik (inorganic)

Pan- afrikan-panafrikan; ballkanik; panballkanik (panafrican)

Ultra- liberal- ultraliberal; tingull-ultratingul (ultraliberal)

Inter- nacional-internacional; urban-interurban (international, interurban)

Auto- biografi -autobiografi; kritike -autokritike (autobiography)

Super- prodhim-superprodhim; (super production)

Poli- klinike- poliklinike; semantik- polisemantik (polisemantic)

\section{Conclusions}

This paper aimed to study some of the main prefixation issues in English and Albanian languages. We have classified the prefixes according to some of their typical features basing on syntactical and morphological properties of prefixes, their level of productivity, their etymology and somehow their transformation with the passing of time etc. What holds true for both languages is the fact that prefixes usually do not change the word classes, but they create a variety of lexemes, meanings. Also, in Albanian language, there are some prefixes which can be used as formation particles and as prepositions. When they are transformed in word formation morphemes they do not have the same lexico-grammatical meaning anymore. Additionally, we have classified the prefixes of both languages according to their meaning and the word classes they are attached to. We provided some English rules that should be taken into consideration in terms of prefix-root correct punctuation; etymology of English prefixes, as well as other relevant issues. In the second part of this paper we have taken a closer look at the main prefixation issues of Albanian language, important characteristics of Albanian prefixes and their combination types.

In conclusion, both languages do have the potential to create new words by means of the prefixation process, by 
which a wide range of new words are formed in English and Albanian languages. We should also mention here the great contribution of English language as a world language in the enrichment of the Albanian language through borrowings, including prefixes. There are various foreign prefixes incorporated into the Albanian language, which has increased the number of Albanian words in different aspects of life.

\section{References}

Akademia e Shkencave te Shqiperise, 1976, Tirane, "Fonetika dhe gramatika e gjuhes se sotme letrare shqipe".pg 35..38.

Akademia e Shkencave, 2002, Tirane "Gramatika e gjuhes shqipe", 1. Morfologjia.

Celiku M, Karapinjalli M, Stringa R, 2007, Tirane "Gramatika praktike e gjuhes shqipe" Toena, pg.303, 304, 305, 310, 327 - 328.

Turn Richard, England 2000," A comprehensible grammar".

Shqerra, E. "C.A of wordformation in English and Albanian languages".2009,pg.6, 32.

Thomai Jani, 2006, Tirane, "Leksikologjia e gjuhes shqipe".

Bauer, L.(1983), "English word-formation". Cambridge University Press, pg.2.

Plag, I (2003),"Word-formation in English" pg.109, 110, 116, 119

Straus J, "The blue book of grammar and punctuation, 10th edition, pg147

Hysa E, "Disa çështje të parashtesimit në gjuhën shqipe", Studime filologjike nr 3, 1973.p15

Hysa E, "Cështje të gramatikës së shqipes së sotme 2", Tiranë, 1975, pg 58

Bauer, Laurie. 2003. English Prefixation, pg.34,35

Kortmann, Bernd. Linguistik: Essentials. Berlin: Cornelsen Verlag, 1999, pg 52.

Marchand, Hans,1969, "The categories and types of present-day English word-formation (2-nd edition)

Lenski, Daniel. 2000. "The Status of Etymology in the Synchronic Morphology of English" pg 4. 